\title{
WATER IMMERSION INCREASES THE CONCENTRATION OF THE IMMUNOREACTIVE N-TERMINAL FRAGMENT OF PROATRIAL NATRIURETIC FACTOR IN HUMAN PLASMA
}

\author{
Alexander L. Gerbes and Angelika M. Vollmar * \\ Department of Medicine II,Klinikum Grosshadern and * Institute \\ of Pharmacology, Toxicology and Pharmacy, University of Munich, \\ Munich,Federal Republic of Germany
}

Received August 31, 1988

Atrial natriuretic factor (ANF) N-terminal (ANF 1-98) and Cterminal (ANF 99-126) fragments were determined by radioimmunoassay in human plasma. Mean basal plasma ANF Nterminal concentrations in 9 healthy subjects were $461 \pm 58$ fmol/ml,significantly $(\mathrm{p}<0.0001)$ higher than ANF c-terminal concentrations $(4.8 \pm 0.5 \mathrm{fmol} / \mathrm{ml})$. Central volume stimulation by one hour head-out water immersion (WI) induced a significant $(p<0.01)$ increase of the $c$-terminal peptide levels to $11.6 \pm$ $2.3 \mathrm{fmol} / \mathrm{ml}$, paralleled by a significant $(p<0.001)$ increase of the $\mathrm{N}$-terminal fragment levels to $749 \pm 96 \mathrm{fmol} / \mathrm{ml}$. Increases of plasma concentrations of both fragments upon WI correlated significantly $(r=0.71 ; p<0.05)$. These data suggest cosecretion of the $\mathrm{N}$-terminal fragment with the c-terminal fragment of pro ANF 1-126 following a physiological stimulus of ANF release in man. 1988 Academic Fress, Inc.

Atrial natriuretic factor (ANF) is stored in atrial granules as 126 amino acid prohormone (for review, see 1). Upon appropriate stimulation, such as atrial stretch (2), it is released and cleaved, and in the plasma the biologically active form has been identified as the 28 amino acid c-terminal fragment ANF 99-126 (3-7). Recently,presence of the $N$-terminal fragment ANF 1-98 has also been demonstrated in plasma of both, rat and man $(8,9)$. This finding together with the observation of increased concentrations of both, N-terminal and c-terminal immunoreactivity following morphine stimulation in rats, suggested cosecretion of both fragments $(8,9)$. The present study addresses the issue of cosecretion in man,applying water immersion (WI) as a physiological stimulus of ANF release (1012). 


\section{MATERIALS AND METHODS}

\section{Subjects}

9 healthy subjects, 5 men and 4 women, aged 30 to 65 (mean $47 \pm$ 3 ) years were investigated after their informed consent had been obtained. The subjects had a normal physical examination and normal routine laboratory tests. They showed no evidence of cardiovascular, renal,pulmonary or endocrine diseases. The subjects were on a regular diet, containing approximately 150 meq sodium and took no medications.

\section{Water immersion}

The protocoll has been specified before $(10,12)$. Briefly: In the morning of the experiment, an intravenous catheter was placed into a forearm vein and subjects sat down comfortably on a chair next to the immersion tank. After 1 hour, they were immersed to their neck into thermoneutral $\left(34.5 \pm 0.2{ }^{\circ} \mathrm{C}\right)$ water for one hour,maintaining the same seated position. This was followed by a 1 hour period of sitting outside the tank. Plasma samples were collected before, after 1 hour WI and 1 hour after the end of WI.

Determination of ANF by radioimmunoassay

C-terminal ANF was determined by RIA, using antiserum Toni III, as described in detail before (6). The RIA procedure for the N-terminal fragment with antibody GT 23 has been reported elsewhere in detail (9).

Chromatographic analysis of ANF immunoreactivity (ir)

Serum was applied to a spherogel TM TSK, 2000 SW column (10 $\mathrm{m}, 7.5 \mathrm{~mm} \times 300 \mathrm{~mm}$; Beckman Instruments, San Ramon, Ca., USA) and eluted with $0.09 \%$ TFA containing $0.005 \mathrm{M} \quad \mathrm{Na}_{2} \mathrm{SO}_{4}, 0.002 \mathrm{M}$ $\mathrm{NaH}_{2} \mathrm{PO}_{4}$ and $30 \%$ acetonitrile; flowrate was $0.3 \mathrm{ml} / \mathrm{min}$. calibration of the column was performed with bovine serum albumin, MW $66 \mathrm{KD}\left(\mathrm{V}_{\mathrm{O}}\right)$, cytochrome $\mathrm{C}, \mathrm{MW} 12.5 \mathrm{KD}$, vitamin $\mathrm{B} 12$, MW $0.7 \mathrm{KD}\left(\mathrm{V}_{t}\right)$, rat pro ANF $2-126, \mathrm{MW} 15 \mathrm{KD}$ and human ANF 99126 , MW $3 \mathrm{KD}$. Fractions $(0.3 \mathrm{ml})$ were lyophilized and tested for ir ANF by both RIA procedures.

Statistical evaluation

Differences between $\mathrm{N}$-terminal and C-terminal concentrations as well as concentrations of the same fragment before and after WI were compared by paired t-test. The Pearson correlation coefficient was determined by the usual linear least squares test. Data are presented as mean and standard error.

\section{RESULTS AND DISCUSSION}

Concentrations and HPLC analysis of $\mathrm{N}$-terminal and $\mathrm{C}$-terminal immunoreactivity in human plasma

The mean plasma concentration of the $\mathrm{N}$-terminal fragment in basal conditions was significantly $(p<0.0001)$ higher than the mean concentration of C-terminal ANF: $461 \pm 58 \mathrm{fmol} / \mathrm{ml}$ as compared to $4.8 \pm 0.5 \mathrm{fmol} / \mathrm{ml}$. This finding is in accordance 

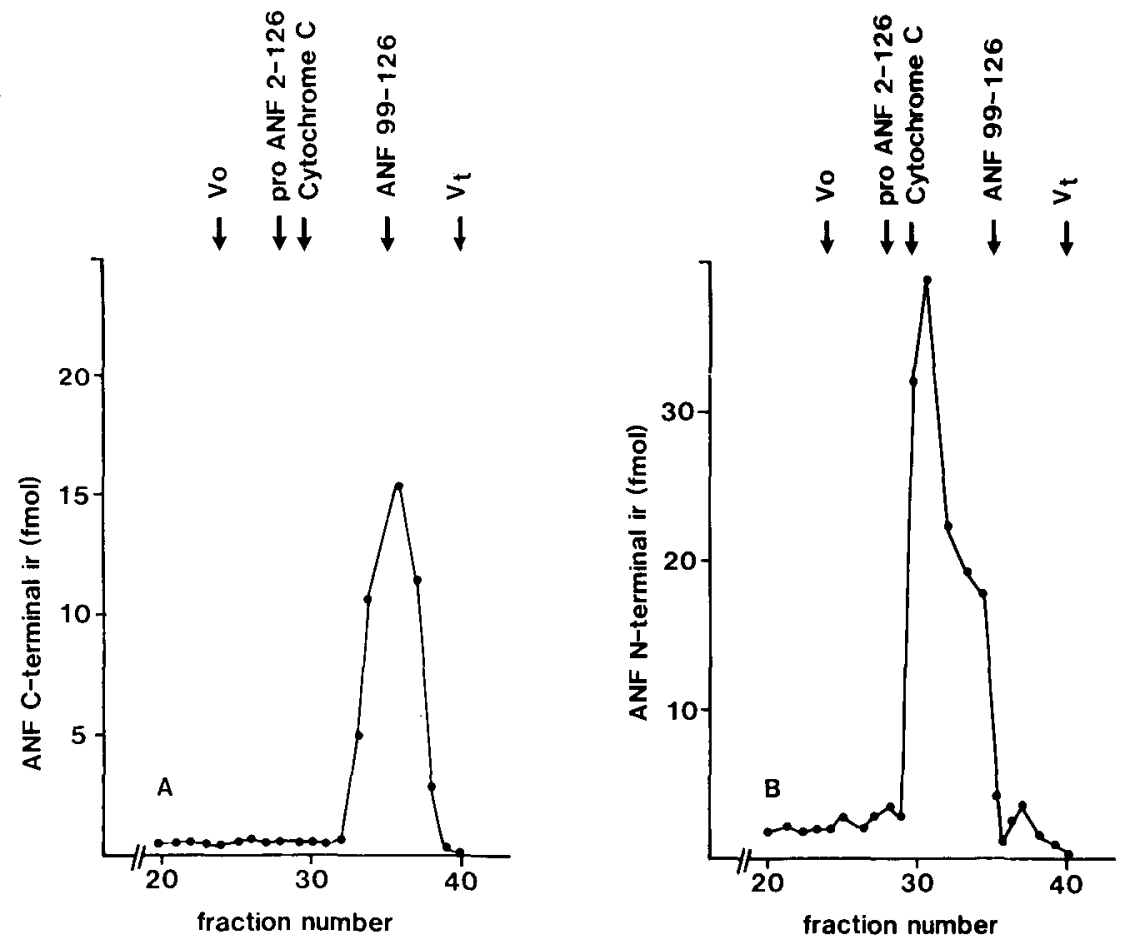

Figure 1

HPLC analysis of C-terminal (panel A) and N-terminal (panel B) ANF immunoreactivity.

The void $\left(\mathrm{v}_{0}\right)$ and total volumes $\left(\mathrm{V}_{t}\right)$ of the column were determined by BSA and vitamin $B$ 12, respectively. Arrows indicate the elution positions of rat pro ANF 2-126, cytochrome $C$ and human ANF 99-126. C-terminal immunoreactivity elutes in the molecular weight range of ANF 99-126, N-terminal immunoreactivity in the range of ANF 1-98.

with recent observations (9) and may be due to a longer elimination half-life of the $\mathrm{N}$-terminal fragment.

Figure 1 shows a HPGPC analysis of C-terminal (panel $A$ ) and Nterminal (panel B) ANF immunoreactivity. The c-terminal ir was detected as a single peak coeluting with synthetic ANF 99-126. The $\mathrm{N}$-terminal ir was eluted as a single peak in the molecular weight range of ANF 1-98.

N-terminal and C-terminal plasma concentrations after stimulation of ANF release

Following immersion plasma concentrations of c-terminal ANF increased significantly $(p<0.01)$ from $4.8 \pm 0.5 \mathrm{fmol} / \mathrm{ml}$ to 11.6 $\pm 2.3 \mathrm{fmol} / \mathrm{ml}$, returning to $5.7 \pm 0.7 \mathrm{fmol} / \mathrm{ml}$ post immersion 

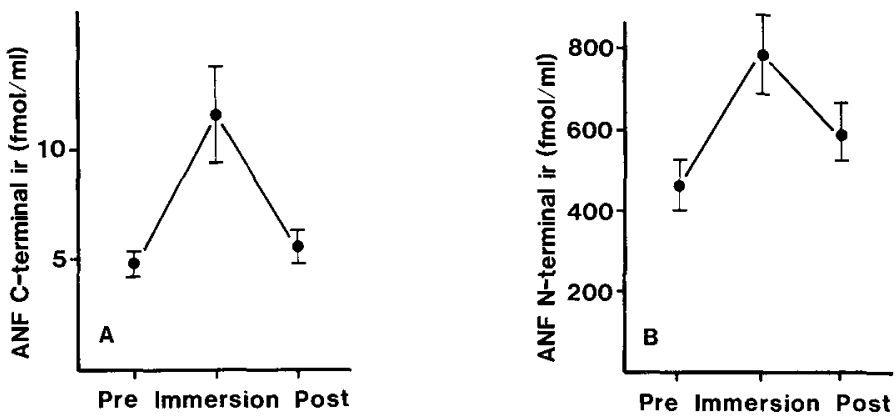

\begin{abstract}
Figure 2
Plasma concentrations of C-terminal and $\mathrm{N}$-terminal ANF immunoreactivity after stimulation of ANF release.

Plasma concentrations (mean \pm standard error) of c-terminal (panel A) and N-terminal (panel B) ANF immunoreactivity before ("Pre"), after one hour water immersion ("Immersion") and one hour after the end of water immersion ("Post") of nine healthy subjects. Immersion induced a significant $(p<0.01)$ increase of both, C-terminal and N-terminal ANF.
\end{abstract}

(figure 2a). This finding is in accordance with previous observations of our $(10,12)$ and of other groups $(11,13-15)$ and supports the contention that central volume stimulation stimulates ANF release. Interestingly, the concentration of the counterpart of the C-terminal fragment, the $\mathrm{N}$-terminal fragment also was found increased upon immersion: plasma levels rose from $461 \pm 58 \mathrm{fmol} / \mathrm{ml}$ to $749 \pm 96 \mathrm{fmol} / \mathrm{ml}(\mathrm{p}<0.001)$ during $W I$, returning to $590 \pm 83 \mathrm{fmol} / \mathrm{ml}$ in the recovery period (figure $2 \mathrm{~b})$. The augmentations of plasma concentration of both fragments by immersion were correlated significantly $(r=0.71, p<0.05)$.

The observation of an increase of the $\mathrm{N}$-terminal in parallel with the c-terminal fragment of pro ANF 1-126 suggests cosecretion of both peptides in man following a physiological stimulus of ANF release.

\title{
ACKNOWLEDGMENTS
}

Drs. M. Cantin and G. Thibault, Clinical Research Institute of Montreal, canada are thanked for providing antiserum GT 23 and for their help in establishing the RIA. Dr. R. Arendt, Dept. of Medicine I,Klinikum Grosshadern,Univ. of Munich,FRG is gratefully acknowledged for donating antiserum Toni III and for his support.Drs. Schöne, Preibisch and Seipke, Hoechst AG, Frankfurt, FRG provided synthetic rat pro ANF 2-126. M.Bauch,G.Hach,F.Höpker and R.Witthaut are thanked for technical assistance. 


\section{REFERENCES}

1. Cantin, M. and Genest, J. (1985) Endocrin. Rev. 6, 107127.

2. Lang, R.E., Thölken, H., Ganten, D., Luft, F.C., Ruskoaho, H. and Unger, T. (1985) Nature 314, 264-265.

3. Schwartz, D., Geller, D.M., Manning, P.T., Siegel, N.R., Fok, K.R., Smith, C.E. and Needleman, P. (1985) Science 229, 397-400.

4. Sugawara, A., Nakao, K., Morii, N., Sakamoto, M., Suda, M., Shimokura, M., Koso, Y., Kihara, M., Yamori, Y., Nishimura, K., Someda, J., Ban, T. and Imura, H. (1985) Biochem. Biophys. Res. Comm. 129, 439-446.

5. Thibault, G., Lazure, E.L., Schiffrin, J., Gutkowska, L., Chartier, R., Garica, R., Seidah, N.G., Chretien, M., Genest, J. and Cantin, M. (1985) Biochem. Biophys. Res. Comm. 130, 981-986

6. Arendt, R.M., Gerbes, A.L., Ritter, D. and Stangl, E. (1986) Klin. Wochenschr. 64 (suppl VI), 97-102.

7. Needleman, P.J. and Greenwald, J.E. (1986) N. Engl. J. Med. $314,828-834$.

8. Thibault, G., Murthy, K.K., Gutkowska, J., Seidah, N.G., Lazure, C., Chretien, M. and Cantin, M. (1988) Peptides 9, 47-53.

9. Sundsfjord, J.A., Thibault, G., Larochelle, P. and Cantin, M. (1988) J. Clin. Endocr. Metab. 66, 605-610.

10. Gerbes, A.L., Arendt, R.M., Schnizer, W. , Silz, S., Jüngst, D., Zähringer, J. and Paumgartner, G. (1986) Klin. Wochenschr. 64, 666-667.

11. Epstein, M., Loutzenhiser, R., Friedland, E., Aceto, R.M., Camargo, M.I.F. and Atlas S.A. (1987) J. Clin. Invest. 79, $738-745$.

12. Gerbes, A.L., Arendt, R.M., Gerzer, R., Schnizer, W., Jüngst, D. and Paumgartner, G. (1988) Eur. J. Clin. Invest., in press.

13. Anderson, J, Struthers, A., Christofides, N. and Bloom, S. (1986) clin. Sci. 70,327-331.

14. Ogihara, T., Shima, J., Hara, H., Tabuchi, Y., Hashizume, K., Nagano, M. , Katahira, K. , Kangawa, K., Matsuo, H. and Kumahara, Y.(1986) Life Sci. 38, 2413-2418.

15. Pendergast, D.R., De Bold, A.J., Pazik, M. and Hong, S.K. (1987) Proc. Soc. Exp. Biol. Med. 184, 429-435. 